\title{
HUBUNGAN ANTARA DUKUNGAN KELUARGA DENGAN PERILAKU IBU DALAM PEMBERIANASI EKSKLUSIF DI DESA TRENYANG WILAYAH KERJA PUSKESMAS SUMBERPUCUNG
}

\author{
Association Between Family Support and Maternal Behaviour for Exclusive Breastfeeding in Trenyang Village \\ in Working Area of Sumberpucung's Community Health Center
}

\author{
1* Ririn Kurniawati, ${ }^{2}$ Wyssie Ika Sari, ${ }^{3}$ Dita Islamiah
}

${ }^{1}$ S1 Keperawatan STIKes Widya Cipta Husada, Jend. Sudirman, Malang, Indonesia

${ }^{2}$ S1 Keperawatan STIKes Widya Cipta Husada, Jend. Sudirman, Malang, Indonesia

${ }^{3}$ S1 Keperawatan STIKes Widya Cipta Husada, Jend. Sudirman, Malang, Indonesia

*e-mail:ribiekurnia@gmail.com

\begin{abstract}
ABSTRAK
Air susu ibu (ASI) merupakan makanan terbaik yang mengandung semua unsur zat gizi yang dibutuhkan bayi usia 0-6 bulan. ASI dapat mempengaruhi tumbuh kembang. Tujuan dari penelitian ini adalah untuk mengidentifikasi hubungan dukugan keluarga dengan perilaku ibu dalam pemberian ASI eksklusif di Desa Trenyang Wilayah Kerja Puskesmas Sumber Pucung. Penelitian ini dilakukan dengan pendekatan case control. Penelitian dilaksanakan di Desa Trenyang Wilayah Kerja Puskesmas Sumber Pucung. Teknik sampling menggunakan purposive sampling pada 96 ibu menyusui anak usia 7-24bulan. Data kemudian diuji dengan menggunakan uji statistik chi square. Hasil uji chi square didapatkan p $(0,015)<0,05$ maka $\mathrm{H}_{1}$ diterima dan ditolak $\mathrm{H} 0$ dengan demikian berarti ada hubungan dukungan keluarga dengan perilaku ibu dalam pemberian ASI eksklusif di desa Trenyang wilayah kerja puskesmas Sumber Pucung. Nilai OR $=2,77$ artinyadukungan keluarga memberi peluang 2,77 kali terhadap dukungan keluarga. Saran hendaknya keluarga selalu meningkatkan dukungan penghargaan pada ibu dalam pemberian ASI eksklusif. Petugas kesehatan diharapkan lebih meningkatkan kerjasama dengan kader posyandu karena dukungan keluarga akan meningkatkan kemandirian pada ibu dalam pemberian ASI eksklusif.
\end{abstract}

Kata kunci : dukungan keluarga,ASI

\section{ABSTRACT}

Mother's Milk (ASI) is the best food that contains all nutrients needed by infants aged 0-6 months. Breast milk can affect the growth and development of bayp. The purpose of this study was to identify the relationship between family support and mother's behavior in providing exclusive ASI in the trenyang village Sumber Pucung health center. This research was conducted with a case control approach. The variable in this study is the dependent variable family support, the independent variable exclusive breast feeding. The research was carried out in trenyang village, the working area of Sumber Pucung, sampling purposive sampling with a large sample of 96 infants aged 7-24 months. Date were then tested using chi square analysis. Chi squere test results obtained $p(0.015)<0.05$ then $\mathrm{Hl}$ is accepted and rejected by HO, which means there is a relationship between family support and maternal behavior in providing exclusive breastfeeding in trenyang village Sumber Pucung. And the value obtained OR $=2.77$ means that family support gives 2.77 times the opportunity for family support. Conclusion of this research is all family give support to mother's behavior in providing exclusive ASI health officer should increase cooperation with mom family because support will increase the mom's self supporting. Health workers are expected to increase cooperation with Posyandu cadres because family support will increase independence for mothers in exclusivebreastfeeding.

Keyword: family support, breastfeeding

\section{PENDAHULUAN}

Menurut WHO sebagai badan PBB yang menangani masalah bidang kesehatan, mengatakan lebih dari 300 penelitian menunjukan bahwa pemberian ASI selama 6 bulan adalah jangka waktu yang paling optimal untuk pemberian ASI ekslusif. Sejalan dengan hasil kajian WHO diatas MENKES melalui KEPMENKES RI NO.450/MENKES/IV/2004 menetapkan 
perpanjangan pemberian ASI secara ekslusif yang semula empat bulan menjadi enam bulan (Kementerian Kesehatan Republik Indonesia, 2017). Pada peringatan hari ASI sedunia di Jakarta, Menteri Kesehatan mengatakan bahwa jumlah ibu menyusui bayi secara eksklusif di Indonesia sangat rendah. Tercatat, yang menyusui hingga 6 bulan hanya 14\%, sementara $64 \%$ hanya sampai usia 3 bulan oleh karena ada keinginan untuk mengganti ASI dengan susu formula serta makanan tambahan ASI (MT ASI) lain sebelum ASI Eksklusif diselesaikan. Bahkan $13 \%$ bayi dibawah dua bulan telah diberi susu formula dan $15 \%$ lainnya telah diberi makanan tambahan pada usia yang sama (BKKBN, 2015).

Menurut data riset kesehatan dasar (Rikesdas) (2015), pemberian ASI eksklusif pada bayi sampai berusia 6 bulan hanya 38\%. Bayi yang mendapat ASI eksklusif di Jawa Timur tahun 2015 sebesar $68,8 \%$,mengalami penurunan dibandingkan dengan tahun 2014 (72,89\%), tetapi kembali meningkat pada tahun 2016 sebesar 75\%. Bayi yang tidak diberi ASI eksklusif selama 6 bulan dapat mempengaruhi status gizi. Pemberian ASI eksklusif dapat membantu mencegah penyakit infeksi pada bayi. penyakit infeksi akan menurunkan nafsu makan pada bayi dan berakibat penurunan status gizi, dari 50 bayi yang tidak diberi ASI eksklusif, $76,7 \%$ diantaranya menderita gizi buruk. Status gizi kurang energi, vitamin A, Zinc, Fe menyebabkan bayi sering mengalami infeksi yang berlangsung lama.

Pada tahun 2009 dilakukan survei terhadap 17 desa dari 4 Kecamatan di Kabupaten Malang, yaitu di Kecamatan Singosari, Jabung, Ngantang, dan Kecamatan Pagelaran yang di dapatkan data jumlah bayi yang diberi ASI ekslusif sebesar 23,53\%. Sedangkan dari laporan Puskesmas tahun 2013 cakupan ASI eksklusif sebanyak 22.585 (54,79\%), tahun 2009 meningkat sebanyak 24.328 $(58,46 \%)$, tahun 2015 ASI eksklusif meningkat sebanyak 15.374 bayi, dan tahun 2011 ASI eksklusif sebanyak 22.156 bayi $(67,86 \%)$ dari 33.199 bayi yang diperiksa. Sedangkan tahun 2016 ASI eksklusif sebanyak 25.689 bayi $(57,90 \%)$ dari 44.367 bayi yang diperiksa, angka ini masih lebih rendah dari target Nasional yaitu $80 \%$.

Cakupan lebih dari $80 \%$ terdapat di 5 Puskesmas yaitu, Singosari, Ardimulyo,
Karangploso, Kromengan, dan Bantur sedangkan cakupan yang dibawah $80 \%$ terdapat di 34 Puskesmas. Data Puskesmas Sumber Pucung jumlah bayi yang di beri ASI eksklusif, bayi laki-laki 243 $(66,58 \%)$ bayi perempuan $209(64,71 \%)$, dari keseluruhan bayi berjumlah 452 (65,70\%). Hal ini masih belum memenuhi target Nasional yaitu di bawah $80 \%$ (Kabupaten Malang, 2017).

ASI merupakan makanan yang paling ideal untuk bayi terutama pada bulan-bulan pertama setelah kelahiran. ASI megandung semua zat gizi untuk membangun dan menyediakan energi dalam susunan yang diperlukan, tidak memberatkan fungsi saluran cerna dan ginjal, menghasilkan pertumbuhan yang optimal, memiliki berbagai zat anti infeksi dan anti alergi, tersedia setiap saat, selalu segar (suhu ideal), bebas pencemaran bakteri (steril), dan yang tidak kalah pentingnya menyusui murah harganya (Mansjoer, 2015).

Dukungan keluarga, dapat menentukan keberhasilan atau kegagalan menyusui, sebab dukungan suami akan menimbulkan rasa nyaman pada ibu sehingga akan mempengaruhi produksi ASI serta meningkatkan semangat dan rasa nyaman (Permatasari, 2015).

Berdasarkan studi pendahuluan di Desa Trenyang Sumber Pucung Kabupaten Malang, dengan keluarga yang mempunyai bayi berusia 7-24 bulan sebanyak 10 orang. Sebagian besar mengatakan bahwa saat bayi usia 0-6 bulan mereka sudah diberikan susu formula sebagai PASI (pengganti air susu ibu) dan makanan tambahan lain misalnya pisang dicampur dengan nasi yang dilumatkan. Menurut keluarga dukungan yang telah di berikan hanya sekedar menyarankan untuk periksa dan rutin ke posyandu tanpa mendampingi, serta hanya memberikan ilmu dan saran saran dari pengalamnya saat mempunyai anak dulu. Hal ini disebabkan oleh keterbatasan informasi yang di berikanoleh petugas kesehatan dan kurangnya pendampingan saat posyandu serta kurangnya dukungan keluarga.

Berdasarkan temuan diatas peneliti ingin mengetahui hubungan dukungan keluarga dengan pemberian ASI eksklusif pada bayi di Desa Trenyang Wilayah Kerja Puskesmas Sumber Pucung Kabupaten Malang. Oleh karena itu tujuan dari 
penelitian ini untuk mengetahui hubungan dukungan keluarga dengan perilaku ibu dalam memberikan asi eksklusif di Desa Trenyang Wilayah Kerja Puskesmas Sumber Pucung Kabupaten Malang diharapkan dengan adanya penelitian ini dapat mengetahui hubungan dukungan keluarga dengan pemberian ASI eksklusif pada bayi.

\section{METODE PENELITIAN}

\section{Jenis dan Rencana Penelitian}

Jenis penelitian yang digunakan adalah deskriptif menggunakan pendekatan case control dengan tujuan untuk mengetahui hubungan dukugan keluarga dengan perilaku ibu dalam pemberian ASI eksklusif di Desa Trenyang wilayah kerja Puskesmas Sumber Pucung.

\section{Populasi dan Sampel}

Populasi dalam penelitian ini adalah seluruh ibuyangmempunyaibalita yang pernah memberikan asi eksklusif berjumlah 180 responden. Pengambilan sampel dalam penelitian ini menggunakan non random sampling yaitu purposive sampling yang artinya sampel diambil berdasarkan pertimbangan tertentu yang dibuat oleh peneliti sendiri. Jumlah sampel penelitian ini sebesar 96 responden remaja dengan gastritis.

\section{Instrumen Penelitian}

Penelitian ini menggunakan instrumen penelitian berbentuk kuesioner dengan jumlah pertanyaan sebanyak 20 item untuk variabel dukungan keluarga dan 10 item untuk variabel perilaku pemberian ASI eksklusif, yang mana menggunakan scala nominal yang sebelumnya di uji validitas dan reabilitas.

\section{Analisis Data}

Analisis pada penelitian ini adalah bivariat dan menggunakan metode analisis data non parametrik atau kategorik, serta jumlah sampel yang banyak, maka uji statistik yang digunakan chi square.

\section{HASIL DAN PEMBAHASAN}

Berdasarkan hasil pada perilaku pemberian ASI ekslusif yang kurang lebih banyak yaitu 49 orang $(51 \%)$ di bandingkan dengan perilaku pemberian ASI eksklusif baik. Berdasarkan hasil tersebut dapat dikatakan bahwa perilaku Pemberian ASI eksklusif dalam kategori kurang.

TABEL 1. Distribusi frekuensi responden berdasarkan variabel dukungan keluarga $(n=96)$

\begin{tabular}{ccc}
\hline Dukungan Keluarga & Frekuensi & Persentase \\
\hline Kurang & 51 & $53,1 \%$ \\
Baik & 45 & $46,9 \%$ \\
Total & 96 & $100 \%$ \\
\hline
\end{tabular}

Perilaku kurang dalam pemberian ASI eksklusif yang dapat disebabkan oleh faktor predisposisi yaitu tingkat pendidikan, semakin tinggi pendidikan seseorang, maka makin mudah untuk menerima informasi sehingga semakin banyak pula pengetahuan yang dimiliki. Sebaliknya pendidikan yang kurang akan menghambat sikap terhadap nilainilai yang baru diperkenalkan, termasuk mengenai ASI eksklusif dan tingkat sosial ekonomi. Faktor pengetahuan yang rendah tentang manfaat dan tujuan pemberian ASI eksklusif bisa menjadi penyebab gagalnya pemberian ASI esklusif pada bayi.

Kemungkinan pada saat pemeriksaan kehamilan (Ante Natal Care), mereka tidak memperoleh penyuluhan intensif tentang ASI eksklusif, kandungan dan manfaat ASI, teknik menyusui, dan kerugian jika tidak memberikan ASI eksklusif, faktor penguat yang meliputi faktor sikap dan psikologis misalnya adanya anggapan para ibu bahwa menyusui akan merusak penampilan dan khawatir akan tampak menjadi tua dan perilaku tokoh masyarakat, tokoh agama, para petugas kesehatan, dan dukungan keluarga yang kurang terutama pada dukungan penilaian yaitu kurang mendapatkan pemberian nasihat dan bimbingan. dari keluarga berupa kurangya keluarga mengingatkanibu untuk memberikan ASI eksklusif.

Friedman (Sudiharto, 2017) menyatakan bahwa fungsi dasar keluarga antara lain adalah fungsi efektif, yaitu fungsi internal keluarga untuk pemenuhan kebutuhan psikososial, saling mengasuh, dan memberikan cinta kasih, serta saling menerima dan mendukung. Suami dan keluarga dapat berperan aktif dalam pemberian ASI dengan cara memberikan dukungan emosional atau bantuan praktis lainnya (Roesli, 2007).

Menurut Purwanto dalam (Pratama, 2013) perilaku manusia berasal dari dorongan baik dari diri 
sendiri maupun dari luar, sedangkan dorongan merupakan suatu usaha untuk memenuhi keinginan individu, dengan kata lain, dorongan mempengaruhi perilaku. Oleh karena itu, dorongan dari orang-orang terdekat baik keluarga, petugas kesehatan dan sebagainya mempengaruhi proses laktasi sehingga dapat membentuk perilaku ibu dalam menyusui secara eksklusif, perilaku dalam memberikan ASI secara eksklusif, dimana perilaku seseorang terhadap objek kesehatan, ada atau tidaknya dukungan masyarakat, informasi yang didapat serta situasi yang memungkinkan ibu mengambil keputusan untuk memberikan MP-ASI secepatnya atau tidak yang berdampak pada perilaku pemberian MPASI (Notoatmodjo, 2015).

Hal ini juga dikarenakan adanya faktor -faktor lain yang mempengaruhi ibu memberikan ASI adalah kurangnya informasi tentang manfaat dan keunggulan ASI, kurangnya pengetahuan ibu tentang upaya mempertahankan kualitas dan kuantitas ASI selama periode menyusui, merasa kurang modern dan menyusui dianggap cara kuno, takut hilangnya kecantikan dan tidak disayang oleh suami serta gencarnya iklan perusahaan susu botol di berbagai media masa. Menurut Rusli (2015), dengan menciptakan sikap yang positif mengenai ASI dan menyusui dapat meningkatkan keberhasilan pemberian ASI secara eksklusif.

Hasil penelitian juga menunjukkan pada dukungan keluarga yang kurang lebih banyak yaitu $51(53,1 \%)$ responden, serta didapatkan data dukungan yang kurang pada $63(65,6 \%)$ responden pada dukungan penilaian, dukungan informasional $43(44,8 \%)$ responden, emosional $43(44,8 \%)$ responden dan instrumental $11(11,5 \%)$ responden.

TABEL 2. Distribusi frekuensi responden berdasarkan macam dukungan keluarga $(n=96)$

\begin{tabular}{lcccc}
$\begin{array}{c}\text { Dukungan } \\
\text { Keluarga }\end{array}$ & \multicolumn{2}{c}{$\begin{array}{c}\text { Dukungan } \\
\text { Baik }\end{array}$} & \multicolumn{2}{c}{$\begin{array}{c}\text { Dukungan } \\
\text { Kurang }\end{array}$} \\
& F & $\%$ & f & $\%$ \\
\hline Informasional & 53 & 55,2 & 43 & 44,8 \\
Penilaian & 33 & 34,4 & 63 & 65,6 \\
Instrumental & 85 & 88,5 & 11 & 11,5 \\
Emosional & 53 & 55,2 & 43 & 44,8 \\
\hline
\end{tabular}

Dukungan keluarga yang terdiri dari dukungan instrumental, informasi, emosional dan penilaian, berdasarkan hasil penelitian di dapatkan nilai yang kurang pada dukungan keluarga pada dukungan penilaian hal ini di karenakan ibu yang kurang mendapatkan pemberian nasihat dan bimbingan dari keluarga berupa kurangnya keluarga mengingatkan ibu untuk memberikan ASI sampai usia bayi 6 bulan tanpa makanan, menanyakan kepada ibu masalah apa yang dihadapi selama masa menyusui, menemani ibu menyusui bayi pada waktu luang, membimbing ibu tentang cara memerahdan menyimpan ASI, serta membimbing ibu cara memberikan ASI kepada bayi sehingga ibu merasa kurang diperhatikan dan kurang mendapatkan penilaian yang positif saat pemberian

ASI dukungan penilaian merupakan bentuk penghargaan dan citra diri anggota keluarga yang dapatmeningkatkan rasa percaya diri.

Hal ini sejalan yang dilakukan oleh Yofie (Hawari, 2001) dimana dukungan keluarga kurang baik lebih dominan (60\%), jika dukungan yang dibutuhkan kurang akan mempengaruhi motivasi ibu dalam melakukan tindakan. Selain hal tersebut, keluarga dalam membuat keputusan ditentukan oleh kemampuan anggota keluarga, tentunya hal ini akan berpengaruh pada dukungan yang diberikan sedangkan penelitian ini sejalan dengan penelitian (Mamankey, 2018) hasil distribusi dukungan keluarga, yang mendapatkan dukungan keluarga yang baik sebanyak 70 orang (68.0\%) dan yang mendapatkan dukungan kurang yaitu 33 orang $(32,0 \%)$.

Berdasarkan hasil yang didapatkan ternyata sebagian besar keluarga sangat mendukung ibu dalam memberikan ASI eksklusif pada bayi dibandingkan keluarga yang kurang mendukung dikarenakan kurang penilaian keluarga dan pemberan nasihat dan bimbingan tentang manfaat memberikan ASI eksklusif. Dukungan keluarga adalah dukungan untuk memotivasi ibu memberikan ASI saja kepada bayinya sampai usia 6 bulan, memberikan dukungan psikologis kepada ibu dan mempersiapkan nutrisi yang seimbang kepada Ibu (Sudiharto, 2015).

\begin{tabular}{|c|c|c|c|}
\hline & \multicolumn{3}{|c|}{$\begin{array}{l}\text { Hubungan antara dukungan keluarga } \\
\text { denganperilaku pemberian ASI eksklusif di } \\
\text { desa Trenyang wilayah kerja puskesmas } \\
\text { Sumber Pucung kabupaten Malang }\end{array}$} \\
\hline Var & iabel & P Value & OR (IK 95\%) \\
\hline \multicolumn{2}{|c|}{$\begin{array}{l}\text { Dukungan keluarga } \\
\text { Perilaku ibu }\end{array}$} & 0,015 & 2,77 \\
\hline
\end{tabular}


Dukungan keluarga yang baik maka perilaku ibu dalam pemberian ASI Eksklusif juga baik, Dukungan keluarga yang diberikan kepada ibu akan mempengaruhikondisi psikolgis ibu, sehingga ibu akan mempunyai motivasi yang kuat untuk berusaha mempraktekkan bagaimana menyusui yang benar dan tepat selama 6 bulan. Faktor eksternal tidak bisa lepas dari faktor internal, sehingga jika keluarga memberikan dukungan kepada ibu maka motivasi ibu akan lebih kuat yang pada akhirnya perilaku ibu dalam memberikan ASI Eksklusif akan baik, sebaliknya bila keluarga tidak memberikan dukungannya, maka perilaku ibu juga tidak baik. Berdasarkan hal tersebut, bila keluarga mendapatkan pengetahuan tentang pemberian ASI Eksklusif dengan benar dan tepat, tidak hanya dari petugas kesehatan faktor penguat lainya dapat melalui keluarga, kemudian pendekatan dengan tokoh masyarakat, serta tokoh agama, yang mengatakan bahwa misalnya menyusui adalah anjuran agama.

Hal ini sejalan dengan penelitian setyowati (2015) mengungkapkan hal yang sama, kurangnya dukungan keluarga dianggap sebagai pihak yang paling berpengaruh tentang keberhasilan ibu dalam pemberian ASI eksklusif. Hal ini juga sejalan dengan penelitian yang di lakukan oleh Fuaddah (2014) menjelaskan bahwa mayoritas responden memiliki perilaku buruk di karenakan faktor dukungan informatif yang kurang dan bahwa sangat penting keluarga juga di berikan pendidikan tentang pemberian ASI eksklusif.

Dukungan atau support dari orang lain atau orang terdekat, sangatlah berperan dalam sukses tidaknya menyusui karena respons yang ditimbulkan oleh rangsangan-rangsangan (stimulus) tertentu, menimbulkan respons-respons yang relatif berubah misalnya dalam pemberian informatif mempengaruhi perilaku kurang baik, respons yang timbul dan berkembang kemudian diikuti oleh stimulus atau rangsangan yang lain. Misalnya Semakin besar dukungan yang didapatkan untuk terus menyusui secara eksklusif adalah sebagai respon terhadap kemampuan untuk dapat bertahan terus untuk menyusui secara eksklusif.

Dukungan informatif yaitu mencakup memberi nasehat, petunjuk-petunjuk, saran-saran tentang mengatasi maslah kesehatan seperti mendampingi ibu konsultasi ke petugas kesehatan untuk memperoleh informasi tentang asi eksklusif, Hal ini juga di dukung penelitian Ginting (2015), ibu yang mendapatkan dukungankeluarga dalam kategori tidak baik mempunyai risiko sebesar 3,26 kali untuk memberikan MP-ASI dini pada bayi usia $<6$ bulan.

\section{KESIMPULAN}

Dukungan Keluarga di Desa Trenyang Wilayah Kerja Puskesmas Sumber Pucung Kab Malang Lebih dari separuh responden dalam katerogi dukungan kurang dan didapatkan data dukungan yang kurang responden pada dukungan penilaian.Perilaku Pemberian ASI Eksklusif di Desa Trenyang Wilayah Kerja Puskesmas Sumber Pucung Kab Malang lebih dari separuh responden dalam katogori perilaku kurang.

Terdapat hubungan yang kuat dan bermakna antara dukungan keluarga dengan perilaku pemberian ASI Eksklusif di Desa Trenyang Wilayah Kerja Puskesmas Sumber Pucung Kab Malang didapatkan $\mathrm{p}$ value pada uji pearson Chi-Square adalah sebesar 0,015 , karena hasil $p$ value $0,015<0,05$. Dengan demikian dapat disimpulkan bahwa dukungan keluarga mempunyai peranpenting dalam menunjang keberhasilan ibu dalam pemberian ASI eksklusif. Dengan dukungan keluarga yang baik maka perilaku ibu dalam pemberian ASI eksklusif juga baik, dukungan keluarga yang diberikan kepada ibu akan mempengaruhi kondisi psikologis ibu, sehingga ibu akan mempunyai motivasi yang kuat untuk berusaha mempraktekkan bagaimana menyusui yang benar dan tepat selama 6 bulan.

Hasil penelitian ini dapat dijadikan bahan acuan dan pembahasan tentang cara melakukan pemberian Asi eksklusif yang benar dan tepat, dan dapat di praktekkan khususnya pada asuhan keperawatan serta dapat dijadikan dasar bagi peneliti selanjutnya tentang dukungan keluarga ataupun pemberian ASI eksklusif.

\section{DAFTAR PUSTAKA}


BKKBN. 2015. Profil Kependudukan dan Pembanguan di Indonesia. BKKBN. 6(2):103.

Kementerian Kesehatan Republik Indonesia. 2015. Infodatin-Situasi dan Analisis ASI Eksklusif. Jakarta, Pusat Data dan Informasi.

Kementerian Kesehatan Republik Indonesia. 2017. Health Profile of Indonesia 2016 : Profil Kesehatan Provinsi Bali. Bali

Mansjoer, A. 2018. Kapita Selekta Kedokteran Edisi ketiga. Media Aesculapius Fakultas KedokteranUI. Jakarta.

Marlyn, F. 2018. Buku Ajar Keperawatan Keluarga: Riset Teori dan Praktik. Jakarta, EGC.

Notoatmodjo, S. 2015. Promosi Kesehatan dan Perilaku Kesehatan. Jakarta, Rineka Cipta.

Nursalam. 2016. Metodologi Penelitian Ilmu Keperawatan, Edisi Empat. Jakarta Selatan, Salemba Medika.

Oktalina, O., Muniroh, L. \& Adiningsih, S. 2015. Dengan Pemberian Asi Eksklusif Pada Ibu Anggota Kelompok Pendukung Asi ( KpAsi ). Media Gizi Indonesia. 2(10):64-70.

Purwanti, H. S. 2018. Konsep Penerapan ASI Eksklusif . Jakarta, EGC.

Ramadani, M \& Hadi, E. 2015. Dukungan Suami dalam Pemberian ASI Eksklusif di Wilayah Kerja Puskesmas Air Tawar Kota Padang
Sumatera barat. Jurnal Kesehatan Masyarakat Nasional. 4(4):6-7.

Rikesdas. 2015. Badan Penelitian dan Pengembangan Kesehatan. Riset Kesehatan Dasar (RISKESDAS). Jakarta, Kementerian Kesehatan RI.

Roesli, U. 2015. Mengenal ASI Eksklusif. Jakarta, Trubus Agriwidaya.

Rusli. 2015. ASI Panduan Praktis Ibu Menyusui. Yogyakarta, Banyu Medika.

Suprajitno. 2015. Asuhan Keperawatan Keluarga Aplikasi dalam Praktik. Jakarta, EGC.

Suprajitno. 2015. Buku Asuhan Keperawatan Keluarga. Jakarta, EGC.

Tyastirin, E., et al. 2017. Statistik Parametrik Untuk Penelitian Kesehatan. Surabaya, Program Studi Arsitektur UIN Sunan Ampel.

Wahyuningsih. 2015. Hubungan Pengetahuan Ibu Bersalin tentang Inisiasi menyusu Dini dengan Pelaksanaan Inisiasi Menyusu Dini di Bidan Praktek Swasta Benis Jayanto Ceper Klaten. Jurnal KlinisKesehatan. 1(2):4-6.

Zaidin, A. 2015. Pengantar Keperawatan Keluarga. Jakarta, EGC.

Zakiyah. 2015. Faktor-Faktor yang Berhubungan dengan Pemberian ASI Eksklusif di Kelurahan Semanan Kecamatan Kalideres Jakarta Barat Tahun 2015. Jurnal Kesehatan Masyarakat. 2(1):1-5. 